\title{
Isolation and characterization of arsenite-resistant human epidermoid carcinoma KB cells
}

\author{
TOKUSHI TACHIWADA ${ }^{1,2^{*}}$, ZHE-SHENG CHEN ${ }^{1,4^{*}}$, XIAO-FANG CHE $^{1}$, MITSUGU MATSUMOTO $^{1,2}$, \\ MISAKO HARAGUCHI $^{1}$, TAKENARI GOTANDA ${ }^{1,2}$, TOMOYUKI SUMIZAWA ${ }^{1,5}$, TATSUHIKO FURUKAWA ${ }^{1}$, \\ KENRYU NISHIYAMA ${ }^{2}$, NAOHIKO SEKI ${ }^{3}$, MASATATSU YAMAMOTO ${ }^{1}$, \\ MASAYUKI NAKAGAWA ${ }^{2}$ and SHIN-ICHI AKIYAMA ${ }^{1}$
}

\author{
Departments of ${ }^{1}$ Molecular Oncology, ${ }^{2}$ Urology, Field of Oncology, Course of Advanced Therapeutics, \\ Kagoshima University Graduate School of Medical and Dental Sciences, 8-35-1 Sakuragaoka, Kagoshima 890-8544; \\ ${ }^{3}$ Department of Functional Genomics, Chiba University Graduate School of Medicine, Chuo-ku, Chiba 260-8670, Japan
}

Received December 28, 2006; Accepted February 6, 2007

\begin{abstract}
Arsenic trioxide $\left(\mathrm{As}_{2} \mathrm{O}_{3}\right)$ has been used with success in the treatment of acute promyelocytic leukemia. However, resistance to arsenite agents reduces their efficacy. We have isolated arsenite-resistant human epidermoid carcinoma KB cells, termed KAS. KAS cells were resistant to sodium arsenite (22-fold) and showed a reduced accumulation of arsenite as a result of an active efflux mechanism. Further analysis indicated that resistance of KAS cells extended to
\end{abstract}

Correspondence to: Dr Shin-ichi Akiyama, Department of Molecular Oncology, Field of Oncology, Course of Advanced Therapeutics, Kagoshima University Graduate School of Medical and Dental Sciences, 8-35-1 Sakuragaoka, Kagoshima 890-8544, Japan

E-mail: akiyamas@m3.kufm.kogoshima-u.ac.jp

Present addresses: ${ }^{4}$ College of Pharmacy and Allied Heath Professions, Department of Pharmaceutical Sciences, St. Albert Hall, Room SB24C, 8000 Utopia Parkway, Jamaica, NY 11439, USA; ${ }^{5}$ Department of Environmental Toxicology, Institute of Industrial Ecological Sciences, University of Occupational and Environmental Health, 1-1 Iseigaoka, Yahatanishi, Kitakyushu 807-8555, Japan

${ }^{*}$ Contributed equally

Abbreviations: MRP1, multidrug resistance protein 1; MRP2, multidrug resistance protein 2; cisplatin, cis-diamminedichloroplatinum(II); VCR, vincristine; ADM, doxorubicin (Adriamycin); VP-16, etoposide; antimony, antimony potassium tartrate; DMEM, Dulbecco's modified Eagle's medium; MTT, 3-(4,5-dimethylthiazol-2-yl)-2,5-diphenyl tetrazolium bromide; PBS, phosphatebuffered saline; GSH, glutathione; GST, glutathione S-transferase; BSO, buthionine sulfoximine

Key words: $\mathrm{ABC}$ transporters, drug resistance, arsenite, cisplatin other drugs including cisplatin (17-fold), antimony potassium tartrate (11-fold) and doxorubicin (27-fold). Although increased expression of multidrug resistance protein 1 (MRP1) in KAS cells was confirmed by quantitative RTPCR and immunoblot analysis, specific inhibitors of MRP1 did not completely eliminate arsenite resistance.

The level of glutathione (GSH) in KAS cells was 3-fold higher than that in KB-3-1 cells, and the inhibition of GSH synthesis by buthionine sulfoximine (BSO) considerably increased the cytotoxic effect of arsenite on KAS cells. A pyridine analog, 2-[4-(diphenylmethyl)-1-piperazinyl ethyl 5(trans-4,6-dimethyl-1,3,2-dioxaphosphorinan-2-yl)-2,6dimethyl-4-(3-nitrophenyl)-3-pyridine-carboxylate P oxide (PAK-104P), partially reversed the arsenite resistance and increased the arsenite accumulation in KAS cells. We suggest that the increased level of GSH is involved in arsenite resistance and an as yet unidentified arsenite transporter is expressed in the arsenite-resistant KAS cells.

\section{Introduction}

Inorganic arsenic is a toxic metalloid that is widely distributed in the environment as a natural component of soil and water. Arsenic has long been known to be a human carcinogen (1). On the other hand, arsenic-containing agents have been used as anti-cancer agents in traditional Chinese medicine (1). Arsenic trioxide $\left(\mathrm{As}_{2} \mathrm{O}_{3}\right)$ has recently become a therapeutic agent of choice for the treatment of acute promyelocytic leukemia and it is a promising novel anticancer agent for the treatment of solid cancers as well. The pro-apoptotic effects of $\mathrm{As}_{2} \mathrm{O}_{3}$ on myeloid leukemia, esophageal carcinoma, ovarian carcinoma and prostate carcinoma cells have been reported in vivo and in vitro (2-5). Several studies indicate that arsenite acts on the mitochondria to induce apoptosis via a direct effect on the permeability transition pore $(6,7)$. Clinical efficiency of anticancer drugs is frequently limited by emergence of various mechanisms of resistance in tumor cells. As observed with various other anticancer drugs, arsenite resistance has been reported at diagnosis or following 
treatment with $\mathrm{As}_{2} \mathrm{O}_{3}$ (8-10). Arsenite resistance has been linked to several metabolic changes, which include differential synthesis of heat-shock proteins (11), inorganic arsenic methylation (12), hyperinducibility of the metallothionein gene (13), and decreased intracellular arsenite accumulation via increased arsenite efflux (14-16).

To understand the molecular basis of arsenite resistance, we have isolated arsenite-resistant cells from human epidermoid carcinoma KB-3-1 cells (KAS). Most of the members of the ABC transporter superfamily function as ATP-dependent active transporters in the plasma membranes and the membranes of intracellular organelles including mitochondria. These proteins are fundamental to membrane transport of a broad variety of substrates including metals and drugs. Members of the ABC superfamily have been implicated in arsenite resistance; the multidrug resistance protein 1 (ABCC1/MRP1) and P-glycoprotein (ABCB1/ MDR1) have been reported to be putative arsenic efflux pumps $(10,15-17)$. Augmentation of the intracellular accumulation of drugs by inhibiting the transporting activity of $\mathrm{ABC}$ transporters is an effective way to reverse drug resistance $(18,19)$.

Here we showed that in KAS cells, the development of arsenite resistance was accompanied by cross-resistance to cisplatin, antimony, and several other anticancer agents. Although we observed the overexpression of $\mathrm{ABCC} 1 / \mathrm{MRP} 1$ in these resistant cells, indirect evidence suggests that glutathione and an as yet undiscovered efflux pump were the major contributors to metal resistance in this cell line.

\section{Materials and methods}

Chemicals. Sodium arsenite, arsenate, antimony potassium tartrate, $\mathrm{CuCl}_{2}$ and $\mathrm{CoCl}_{2}$ were obtained from Wako Pure Chemical Industries Ltd. (Osaka, Japan). Cisplatin, vincristine (VCR), doxorubicin (ADM) and paclitaxel were purchased from Sigma Chemical Co. (St. Louis, MO). PAK-104P, ONO-1078 and MK571 ((E)-3-[[[3-[2-(7-chloro-2quinolinyl)ethenyl]phenyl]-[[3-dimethylamino]-3-oxopropyl]thio]methyl]thio)-propanoic acid), were obtained from Nissan Chemical Inc., Ltd. (Chiba, Japan), Ono Pharmaceutical Ltd. (Osaka, Japan), and Alexis (San Diego, CA), respectively.

Cell culture and chronic arsenite exposure. KB-3-1 and $\mathrm{KB} / \mathrm{MRP}$ cells were incubated in Dulbecco's modified Eagle's medium (DMEM) (Nissui Seiyaku Co., Tokyo, Japan) containing $10 \%$ fetal calf serum. Arsenite-resistant KAS cells were selected from KB-3-1 cells in medium by stepwise increasing concentrations $(5,7,10,12$ and $15 \mu \mathrm{M})$ of sodium arsenite over a period of 12 months.

Cell survival by MTT assay. The MTT colorimetric assay was used to assess the sensitivity of the cells to agents in vitro as described (20).

$R T-P C R$ analysis. Total cellular RNA was extracted by a single-step method using TRIzol (Invitrogen, Carlsbad, CA). For RT-PCR, $1 \mu \mathrm{g}$ of total RNA was used for cDNA synthesis using ReverTraAce- $\alpha$ (Toyobo, Osaka, Japan), according to the manufacturer's protocol. Expression of $M R P 1$ and $M R P 2$ was detected by RT-PCR specific primers for the genes.

Quantitative real-time PCR. Quantitative real-time PCR assays were performed using an ABI PRISM 7900HT sequence detector (Applied Biosystems Japan, Ltd.). The probe was labeled with the reporter fluorescent dye FAM (6carboxyfluorescein) at the 5' end and a quencher fluorescent dye TAMRA (6-carboxy-tetramethylrhodamine) at the 3' end. An ABI PRISM 7900HT sequence detector was used to measure fluorescent emission synchronized with the thermal cycler during each extension step. Relative quantification of GAPDH, MRP1 and MRP2 was calculated by the comparative cycle threshold method. The conditions for the RT-PCR were as follows: $2 \mathrm{~min}$ at $50^{\circ} \mathrm{C}, 10 \mathrm{~min}$ at $95^{\circ} \mathrm{C}$, and then 40 cycles of amplification in TaqMan Universal PCR Master mix (Roche, Branchburg, NJ) at $95^{\circ} \mathrm{C}$ for $15 \mathrm{sec}$ and annealing and extension at $60^{\circ} \mathrm{C}$ for $1 \mathrm{~min}$. Experiments were performed in triplicate for each data point. Each quantitation was performed with the standard curve method.

The sequence of the primer/probe sets used for this analysis are as follows: MRP1, forward 5'-AGGCGAGTG TCTCCCTCAAA-3', reverse 5'-TCCTCACGGTGATGCTG TTC-3', probe 5'-FAM-TGACAGCATCGAGCGACGGCCTAMRA-3'; and MRP2, forward 5'-GAAGACGATGACTA TGGGCTGATAT-3', reverse 5'-GTGTTCGACGAAAGCT GTTCTCT-3', probe 5'-FAM-AGAGATCCCCGAAGATGC AGCCTCC-TAMRA-3'.

Preparation of crude membrane fractions. Cells were washed and scraped with a rubber scraper into PBS containing $1 \%$ aprotinin (Sigma Chemical Co.) and centrifuged at $1000 \mathrm{x} \mathrm{g}$ for $3 \mathrm{~min}$. The pellet was homogenized in hypotonic lysis buffer containing $10 \mathrm{mM}$ Tris $\mathrm{HCl}$ (pH 8.0), $10 \mathrm{mM} \mathrm{KCl,} 1 \mathrm{mM}$ $\mathrm{MgCl}_{2}$, and $1 \mathrm{mM} \mathrm{p}$-amidinophenyl methanesulfonyl fluoride hydrochloride (Wako), and centrifuged at $1000 \mathrm{x} g$ for $10 \mathrm{~min}$ at $4{ }^{\circ} \mathrm{C}$. The supernatant fraction was saved as a postnuclear supernatant and was centrifuged at $23,400 \mathrm{x}$ g for $30 \mathrm{~min}$ at $4^{\circ} \mathrm{C}$ to separate the cytosol and crude membrane fractions.

Immunoblotting. Crude membranes were subjected to $7.5 \%$ SDS-PAGE under reducing conditions according to the method of Laemmli. Two thousand-fold diluted antibody against FLAG epitope was used as the first antibody and the appropriate horseradish peroxidase conjugated anti-mouse IgG (Amersham, Buckinghamshire, UK) was used as the secondary antibody. Immunoreactive bands were visualized with the ECL Western blotting detection system (Amersham). For detection of MRP1 protein, MRPm6 (epitope amino acids 1389-1351), a monoclonal antibody against MRP1 was purchased from Progen Biotechnick (Heidelberg, Germany). For detection of P-glycoprotein, C-219 (Centocor, Inc., Malvern, PA) a monoclonal antibody against P-glycoprotein was used.

Arsenite accumulation. To measure arsenite accumulation, KB-3-1 and KAS cells in 100-mm plastic dishes were incubated for 2 days in DMEM containing $10 \%$ fetal calf serum and then incubated for $2 \mathrm{~h}$ at $37^{\circ} \mathrm{C}$ in medium with sodium arsenite at the indicated concentrations. For the 
Table I. Cross resistance to arsenite and other heavy metals and drugs in KAS cells.

\begin{tabular}{|c|c|c|c|}
\hline \multirow[t]{2}{*}{ Agent } & \multicolumn{2}{|c|}{$\mathrm{IC}_{50}(\mu \mathrm{M})$} & \multirow[t]{2}{*}{ Relative resistance } \\
\hline & KB-3-1 & KAS & \\
\hline Arsenite & $15.2 \pm 1.17$ & $335 \pm 42.9$ & $22.0^{\mathrm{b}}$ \\
\hline Arsenate & $199 \pm 7.7$ & $316 \pm 45.6$ & 1.6 \\
\hline Antimony & $16.6 \pm 0.47$ & $180 \pm 5.15$ & $10.8^{\mathrm{b}}$ \\
\hline Cisplatin & $0.36 \pm 0.01$ & $6.01 \pm 1.11$ & $16.7^{\mathrm{b}}$ \\
\hline $\mathrm{CuCl}_{2}$ & $8.5 \pm 0.77$ & $15.7 \pm 1.59$ & 1.8 \\
\hline $\mathrm{CoCl}_{2}$ & $8.1 \pm 0.55$ & $8.2 \pm 0.81$ & 1.0 \\
\hline VCR & $0.018 \pm 0.0007$ & $0.061 \pm 0.0094$ & $3.4^{\mathrm{b}}$ \\
\hline $\mathrm{ADM}$ & $0.040 \pm 0.010$ & $1.09 \pm 0.29$ & $27.3^{\mathrm{b}}$ \\
\hline Paclitaxel & $0.26 \pm 0.013$ & $0.49 \pm 0.006$ & 1.9 \\
\hline
\end{tabular}

${ }^{\mathrm{a} C e l l ~ s u r v i v a l ~ w a s ~ d e t e r m i n e d ~ b y ~ M T T ~ a s s a y . ~ V a l u e s ~ a r e ~ t h e ~ m e a n s ~} \pm$ SD from triplicate determinations; ${ }^{\mathrm{b}} \mathrm{P}<0.01$.

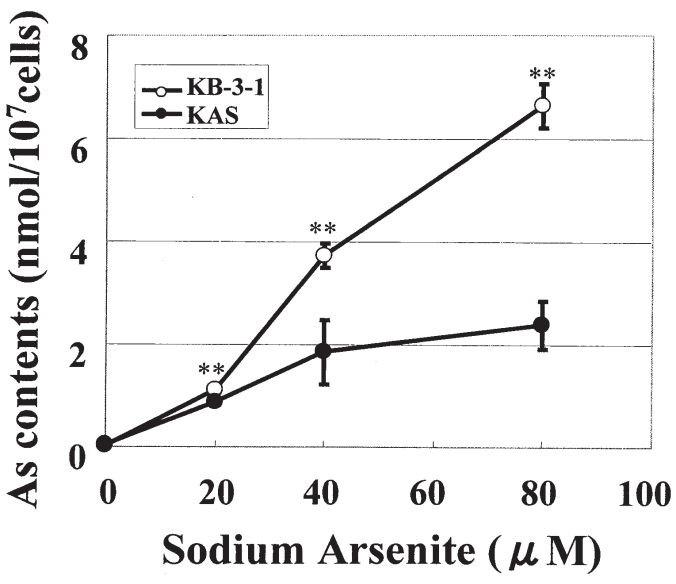

Figure 1. Accumulation of arsenite (As) in KB-3-1 and KAS cells. Accumulation of arsenite in KB-3-1 and KAS cells was measured after incubation with 20,40 and $80 \mu \mathrm{M} \mathrm{As}_{2} \mathrm{O}_{3}$ for $2 \mathrm{~h}$. Bars represent the means \pm SD of triplicate determinations; ${ }^{* *} \mathrm{P}<0.01$.

arsenite accumulation affected by BSO and PAK-104P, KB3-1 and KAS cells in 60-mm plastic dishes were incubated with or without $20 \mu \mathrm{M}$ BSO or $10 \mu \mathrm{M}$ PAK-104P for 2 days, and then incubated with $40 \mu \mathrm{M}$ sodium arsenite for $1 \mathrm{~h}$ at $37^{\circ} \mathrm{C}$. The cells were washed three times with cold PBS and immediately harvested with a rubber scraper. The harvested cells were again washed three times with cold PBS. Cell pellets were hydrolyzed in nitric acid, and total arsenite content was determined by graphite furnace atomic absorption spectrophotometry (GFAAS) using a model Solaar MQZ (Thermo Elemental, Franklin, MA).

Arsenite efflux. The cells were incubated with $500 \mu \mathrm{M}$ arsenite for $10 \mathrm{~min}$ in glucose-free DMEM medium with $1 \mathrm{mM}$ dinitrophenol at $37^{\circ} \mathrm{C}$. Each dish was washed once with PBS, and fresh DMEM medium without arsenite was added, and the cells were incubated in the absence or presence of $1 \mathrm{mM}$ dinitrophenol for the indicated times at $37^{\circ} \mathrm{C}$ and harvested. Arsenite content was determined as described above.
GSH assay. Harvested cells were suspended in $80 \mu 1$ of $10 \mathrm{mM}$ $\mathrm{HCl}$, frozen and thawed twice. The lysates were centrifuged at $8,000 \mathrm{x} \mathrm{g}$ for $10 \mathrm{~min}$, next the supernatant was collected and the GSH levels were measured with the total glutathione quantification kit (Dojin Molecular Technologies, Inc., Gaithersburg, MD).

Statistical analysis. Differences between groups were analyzed by the Student's t-test. $\mathrm{P}<0.05$ was considered significant. Significance levels given are those for the two-tailed Student's t-test.

\section{Results}

Development of arsenite-resistant cancer cells. To isolate arsenite-resistant KAS cells, KB-3-1 cells were cultured in selection medium containing stepwise increases in sodium arsenite concentrations from 5-15 $\mu \mathrm{M}$.

Cross resistance to heavy metals and drugs. We tested the drug sensitivity of each cell line by the MTT assay. Table I shows the $\mathrm{IC}_{50}$ of various metal compounds for the parental and resistant cell lines. KAS cells were 22.0-, 16.7-, and 10.8 -fold resistant to sodium arsenite, cisplatin and antimony potassium tartrate, respectively, as compared to KB-3-1 cells. KAS cells were also 3.4-, 27.3-, and 1.9-fold more resistant to VCR, ADM and paclitaxel, respectively.

Arsenite accumulation. To investigate whether KAS cells acquired resistance to arsenite through decreased accumulation, the accumulation of arsenite in KB-3-1 and KAS cells was examined. When the cells were incubated in medium containing 20, 40 and $80 \mu \mathrm{M}$ sodium arsenite, the accumulation of arsenite in KAS cells was 78, 50 and $36 \%$ of that observed in KB-3-1 cells, respectively (Fig. 1).

Efflux of arsenite. We examined whether or not the decreased accumulation of arsenite in KAS cells was due to enhanced efflux of arsenite. Efflux of arsenite as a function of time after a 2 -h period of accumulation is shown in Fig. 2. 


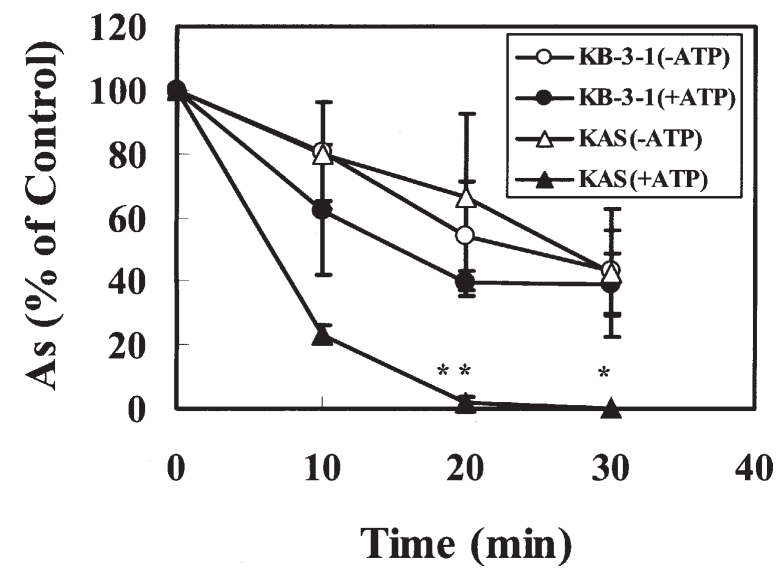

Figure 2. Efflux of arsenite (As). KB-3-1 and KAS cells were incubated for $10 \mathrm{~min}$ in glucose-free DMEM with $1 \mathrm{mM}$ dinitrophenol and $500 \mu \mathrm{M}$ $\mathrm{As}_{2} \mathrm{O}_{3}$. Next the medium was removed, and the cells were washed 3 times with PBS. The cells were incubated in DMEM medium without $1 \mathrm{mM}$ dinitrophenol (closed symbols) or in glucose-free DMEM with $1 \mathrm{mM}$ dinitrophenol (open symbols) and harvested at the indicated times and arsenite content was determined. Values represent the means $\pm \mathrm{SD}$ of triplicate determinations; ${ }^{* *} \mathrm{P}<0.01$ and ${ }^{*} \mathrm{P}<0.05$.

KAS cells actively released a higher percentage of arsenite than KB-3-1 cells. At 10 min, $80 \%$ of cell-associated arsenite was lost from KAS cells, while only $35 \%$ of the accumulated arsenite was effluxed from KB-3-1 cells. The loss of intracellular arsenite was ATP-dependent, as indicated by the failure to see efflux in cells incubated in glucose-free medium with dinitrophenol, suggesting the involvement of (an) active efflux mechanism(s).

Expression of efflux pumps known to confer arsenite resistance. $\mathrm{ABC}$ transporters promote the active efflux of a wide variety of solutes across cellular membranes. To date, two members of the superfamily have been implicated in arsenite efflux; ABCC1/MRP1 and ABCB1/MDR1 $(10,16,17,22)$. Therefore we examined the expression levels of MRP1 and P-glycoprotein in KAS cells by Western blot analysis (Fig. 3).

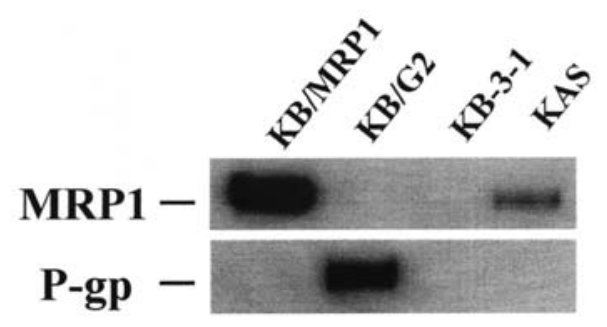

Figure 3. Immunoblot analyses for MRP1 and P-glycoprotein expression. Crude membranes (20 $\mu \mathrm{g}$ of protein) from KB/MRP1, KB/G2, KB-3-1 and KAS cells were separated by SDS-PAGE and transferred to polyvinylidene difluoride membranes. Immunoblot analyses of the transferred proteins with antibodies against MRP1 or P-glycoprotein were performed as described in Materials and methods.

Compared to KB-3-1 cells, ABCC1/ MRP1 showed slightly increased expression in KAS cells. This was, however, significantly less than that observed in KB/MRP1 cells which overexpressed MRP1 (Fig. 3). Since KB/MRP1 cells showed only a modest (2.7-fold as compared to KB-3-1) resistance to arsenite, the level of MRP1 expression in KAS cells did not explain the complete multidrug resistance phenotype or the large decrease in accumulation of sodium arsenite in the KAS cells. In contrast to MRP1, P-glycoprotein was not detected in the protein levels in any of the cells $(\mathrm{KB} / \mathrm{G} 2$, a cell line overexpressing P-glycoprotein, is shown as a control).

RT-PCR analysis confirmed increased expression of $\mathrm{ABCC} 1 / \mathrm{MRP} 1$ in KAS cells, while the expression of $\mathrm{ABCC} 2 / \mathrm{MRP} 2$ was found to be similar in the resistant and parental cells (Fig. 4A). Using real-time PCR assays, the mRNA level of $M R P 1$ was further quantified. The expression levels of MRP1 mRNA in KAS cells were 2.5-fold higher than in KB-3-1 cells (Fig. 4B).

Reversal of resistance to arsenite in KAS cells by PAK-104P and $B S O$. We examined the cytotoxic effect of BSO, an inhibitor of GSH synthesis, and PAK-104P, a P-glycoprotein and MRP1 inhibitor $(23,24)$, using the MTT assay. BSO $(100 \mu \mathrm{M})$ and PAK-104P $(10 \mu \mathrm{M})$ had no cytotoxic effects on KB-3-1 or KAS cells (data not shown). At $10 \mu \mathrm{M}$, BSO
A

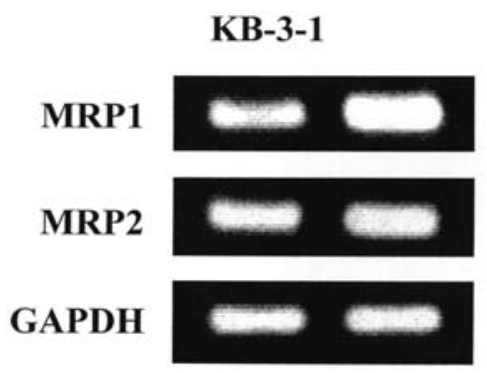

B

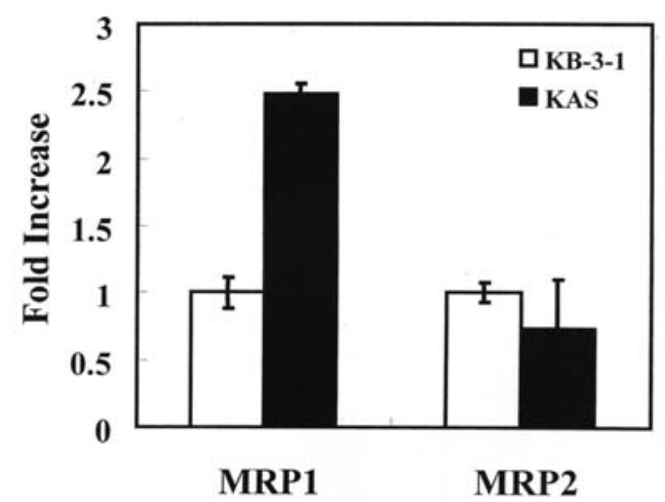

Figure 4. Expression of MRP1 and MRP2 mRNAs. (A) Expression of MRP1 and MRP2 mRNAs in KB-3-1 and KAS cells was detected by RT-PCR. (B) Relative levels of mRNA of MRP1 and MRP2 in KB-3-1 and KAS cells were determined by quantitative real-time PCR. GAPDH was quantified to normalize the mRNA levels of the ABC transporters. Each bar represents the mean $\pm \mathrm{SD}$ of 3 experiments. 
Table II. The effect of PAK-104P on the sensitivity to arsenite in KB-3-1 and KAS cells.

\begin{tabular}{|c|c|c|c|c|}
\hline & \multicolumn{2}{|c|}{ KB-3-1 } & \multicolumn{2}{|c|}{ KAS } \\
\hline & $\mathrm{IC}_{50}(\mu \mathrm{M})$ & $\mathrm{DMF}^{\mathrm{a}}$ & $\mathrm{IC}_{50}(\mu \mathrm{M})$ & DMF \\
\hline+ PBS & $15.2 \pm 1.17$ & & $335 \pm 22.0$ & \\
\hline$+\mathrm{BSO}$ & $0.713 \pm 0.065$ & 21.30 & $2.71 \pm 0.204$ & 124.00 \\
\hline + PAK-104P & $4.45 \pm 0.159$ & 3.42 & $58.9 \pm 7.47$ & 5.68 \\
\hline + MK-571 & $9.62 \pm 0.117$ & 1.58 & $118 \pm 5.36$ & 2.83 \\
\hline + ONO-1078 & $11.3 \pm 0.418$ & 1.34 & $109 \pm 2.63$ & 3.07 \\
\hline
\end{tabular}

${ }^{\text {aDMF}}$, dose-modifying factor (the $\mathrm{IC}_{50}$ value of arsenite in cells was divided by the $\mathrm{IC}_{50}$ value of arsenite combined with $10 \mu \mathrm{M}$ BSO, $10 \mu \mathrm{M}$ PAK-104P, $10 \mu \mathrm{M}$ MK571 or $50 \mu \mathrm{M}$ ONO-1078).

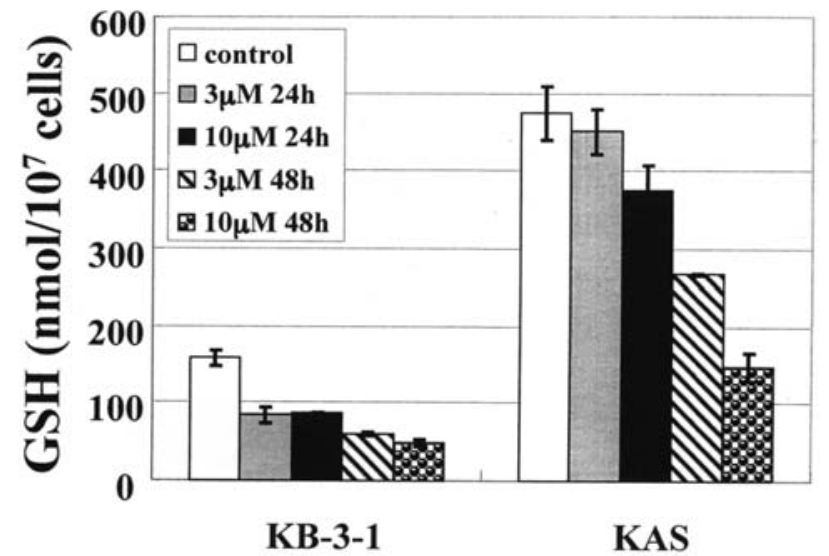

Figure 5. Effect of BSO on GSH level. Cells were incubated in the absence or presence of the indicated concentrations of BSO for 24 and $48 \mathrm{~h}$. After harvesting the cells, intracellular GSH levels in the cells were measured using a total glutathione quantification kit. Columns represent the means of triplicate determinations; bars represent SD.

increased the sensitivity to arsenite of KB-3-1 and KAS cells 21.3- and 124-fold, respectively.

PAK-104P at $10 \mu \mathrm{M}$ increased the sensitivity to arsenite of KB-3-1 and KAS cells 3.4- and 5.7-fold, respectively (Table II). Specific inhibitors of MRP1, MK571 at $10 \mu \mathrm{M}$ and ONO-1078 at $50 \mu \mathrm{M}(25)$, increased the sensitivity to arsenite of KAS cells 2.8- and 3.1-fold, respectively (Table II). To explore the role of intracellular GSH levels, we measured the baseline intracellular GSH levels as well as the effect of BSO treatment on arsenite resistance. Fig. 5 shows that in KAS cells, the baseline level of GSH was 3-fold higher than in KB-3-1 cells.

Treatment of KAS cells with $10 \mu \mathrm{M}$ BSO for $48 \mathrm{~h}$ reduced the GSH level to that found in KB-3-1 cells. As a result of an active efflux mechanism, KAS cells exhibited a reduced accumulation of arsenite as compared to KB-3-1 cells . Treatment with BSO eliminated this difference (Fig. 6), suggesting that the elevated GSH levels contributed to the reduced arsenite accumulation in KAS cells.

The accumulation of arsenite in KAS cells was $26 \%$ of that in KB-3-1 cells and the accumulation in KAS cells in the presence of $20 \mu \mathrm{M}$ BSO or $10 \mu \mathrm{M}$ PAK-104P was comparable to that in KB-3-1 cells in the absence of BSO (Fig. 6).

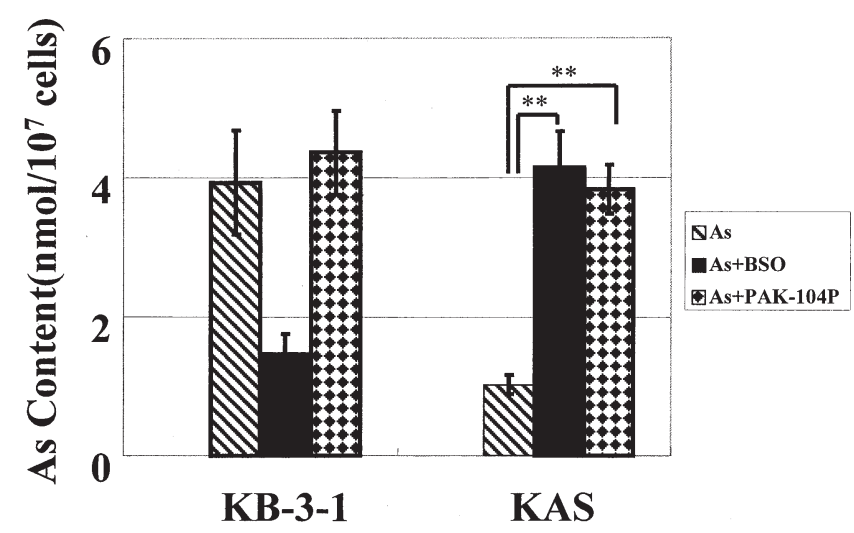

Figure 6. The effect of BSO and PAK-104P treatment on the cellular accumulation of arsenite (As). Cells were incubated in the absence or presence of $20 \mu \mathrm{M}$ BSO or $10 \mu \mathrm{M}$ PAK-104P for $48 \mathrm{~h}$, then incubated with $40 \mu \mathrm{M}$ arsenite for $1 \mathrm{~h}$ and arsenite contents in the cells were determined by GFAAS. Columns represent the means of triplicate determinations; bars represent SD.

\section{Discussion}

To investigate the molecular basis for acquired metal resistance, we isolated arsenite-resistant human epidermoid carcinoma KAS cells. The KAS cells were also resistant to other metals such as cisplatin and antimony. Based on efflux experiments, inhibition studies, and/or immunoblotting studies, we concluded that an active efflux pump for arsenite, different from P-glycoprotein and MRP1, was expressed in KAS cells.

Arsenite is also thought to induce apoptosis by generating reactive oxygen species and abrogating the cellular redox system $(26,27)$. The GSH redox system represents one of the most important cellular defense systems against oxidative stress, and mitochondria are known to have high levels of GSH (26). The cellular and mitochondrial toxicity of arsenite presumably results from the interaction with the thiol groups of proteins (28).

Arsenite triggers a burst of reactive oxygen species (ROS) that is implicated in arsenite-induced cytotoxicity in mammalian cells (29). GSH acts as a primary defense against this excessive generation of cytotoxic ROS (30). In accordance with these reports, BSO decreased the intracellular GSH 
level considerably, and increased the sensitivity of both KAS and KB-3-1 cells to arsenite. The baseline level of GSH in KAS cells was 3 -fold higher than that in KB-3-1 cells, and the inhibition of GSH synthesis by BSO greatly increased the cytotoxic effect of arsenic on KAS cells. The accumulation of arsenite in KAS cells was $\sim 4$-fold increased in the presence of BSO. GSH is also known to be a cofactor for transport by several $\mathrm{ABC}$ transporters in the ABCC (MRP) family and reduction of GSH levels might reduce efficiency of such a transporter (31).

Recent studies have indicated that MRP1 may be an arsenite efflux pump that effluxes arsenite in coordination with GSH and GST $(15,16)$. MRP1 was up-regulated in KAS cells, but specific inhibitors of MRP1, MK571 and ONO-1078, only partially reversed the resistance of KAS cells to arsenite, suggesting that MRP1 may partly be responsible for the phenotype. We have previously reported that MRP1-overexpressing $\mathrm{KB} / \mathrm{MRP}$ cells were only 1.6-fold more resistant to sodium arsenite (32). A still unknown arsenite transporter seemed to be expressed in KAS cells. PAK-104P which inhibited the transporting activity of both P-glycoprotein and MRP1 increased the sensitivity to arsenite more extensively than ONO-1078 and MK571. PAK-104P increased the intracellular level of arsenite in KAS cells comparable to that in KB-3-1 cells. These findings suggested that PAK-104P may suppress the transporting activity of the arsenite efflux pump that is as yet unknown but supposed to be expressed in KAS cells. Lee et al isolated arsenite-resistant cells (R15) from a human adenocarcinoma cell line (CL3) (33). R15 cells were 10 -fold more resistant to sodium arsenite, and the expression level of MRP2 mRNA was higher than that in the CL3 cells.

We previously established stable MRP2 cDNAtransfected cells, LLC/cMOAT-1 from LCC-PK1 cells, and found that LLC/cMOAT-1 cells did not have increased resistance to sodium arsenite compared with LLC-PK1 cells (34). In the present study, the expression level of MRP2 mRNA in KAS cells was comparable to that in KB-3-1 cells. These findings suggest that MRP2 is not involved in arsenite resistance in KAS cells.

Taken together, our results suggest that KAS cells become resistant through a mechanism involving increased cellular GSH and efflux of arsenite. Our data indicate that an active efflux pump for arsenite, different from P-glycoprotein, MRP1 and MRP2 is expressed in KAS cells, and the function may be suppressed by BSO and PAK-104P. Further studies will be needed to characterize the mechanism that is responsible for arsenite efflux.

A better understanding of the mechanism of the resistance to arsenite in KAS cells will help to design agents to reverse clinical arsenite resistance.

\section{Acknowledgements}

We thank Drs Michael M. Gottesman, Gergely Szakács and Jill K. Paterson (Laboratory of Cell Biology, NCI, NIH) for discussions. We also thank Dr Akira Ohki and Mr. Kawahara (Kagoshima University) for their useful technical advice and assistance.

\section{References}

1. Zhu J, Chen Z, Lallemand-Breitenbach V and de The H: How acute promyelocytic leukaemia revived arsenic. Nat Rev Cancer 2: 705-713, 2002.

2. Wang Z, Rivi R, Delva L, et al: Arsenic trioxide and melarsoprol induce programmed cell death in myeloid leukemia cell lines and function in a PML and PML-RARalpha independent manner. Blood 92: 1497-1504, 1998.

3. Uslu R, Sanli UA, Sezgin C, Karabulut B, Terzioglu E, Omay SB and Goker E: Arsenic trioxide-mediated cytotoxicity and apoptosis in prostate and ovarian carcinoma cell lines. Clin Cancer Res 6: 4957-4964, 2000.

4. Shen ZY, Tan LJ, Cai WJ, Shen J, Chen C, Tang XM and Zheng MH: Arsenic trioxide induces apoptosis of oesophageal carcinoma in vitro. Int J Mol Med 4: 33-37, 1999.

5. Maeda H, Hori S, Nishitoh H, Ichijo H, Ogawa O, Kakehi Y and Kakizuka A: Tumor growth inhibition by arsenic trioxide $\left(\mathrm{As}_{2} \mathrm{O}_{3}\right)$ in the orthotopic metastasis model of androgenindependent prostate cancer. Cancer Res 61: 5432-5440, 2001.

6. Kroemer $\mathrm{G}$ and de The H: Arsenic trioxide, a novel mitochondriotoxic anticancer agent? J Natl Cancer Inst 91: 743-745, 1999.

7. Larochette N, Decaudin D, Jacotot E, et al: Arsenite induces apoptosis via a direct effect on the mitochondrial permeability transition pore. Exp Cell Res 249: 413-421, 1999.

8. Takeshita A, Shinjo K, Naito K, et al: P-glycoprotein (P-gp) and multidrug resistance-associated protein 1 (MRP1) are induced by arsenic trioxide $\left(\mathrm{As}_{2} \mathrm{O}_{3}\right)$, but are not the main mechanism of $\mathrm{As}_{2} \mathrm{O}_{3}$-resistance in acute promyelocytic leukemia cells. Leukemia 17: 648-650, 2003.

9. Soignet SL, Maslak P, Wang ZG, et al: Complete remission after treatment of acute promyelocytic leukemia with arsenic trioxide. N Engl J Med 339: 1341-1348, 1998.

10. Vernhet L, Allain N, Payen L, Anger JP, Guillouzo A and Fardel O: Resistance of human multidrug resistance-associated protein 1-overexpressing lung tumor cells to the anticancer drug arsenic trioxide. Biochem Pharmacol 61: 1387-1391, 2001.

11. Lee TC, Ko J and Jan KY: Differential cytotoxicity of sodium arsenite in human fibroblasts and Chinese hamster ovary cells. Toxicology 56: 289-299, 1989.

12. Aposhian HV: Enzymatic methylation of arsenic species and other new approaches to arsenic toxicity. Annu Rev Pharmacol Toxicol 37: 397-419, 1997.

13. Zhao CQ, Young MR, Diwan BA, Coogan TP and Waalkes MP: Association of arsenic-induced malignant transformation with DNA hypomethylation and aberrant gene expression. Proc Natl Acad Sci USA 94: 10907-10912, 1997.

14. Romach EH, Zhao CQ, Del Razo LM, Cebrian ME and Waalkes MP: Studies on the mechanisms of arsenic-induced self tolerance developed in liver epithelial cells through continuous low-level arsenite exposure. Toxicol Sci 54: 500-508, 2000.

15. Liu J, Chen H, Miller DS, et al: Overexpression of glutathione $\mathrm{S}$-transferase II and multidrug resistance transport proteins is associated with acquired tolerance to inorganic arsenic. Mol Pharmacol 60: 302-309, 2001.

16. Brambila EM, Achanzar WE, Qu W, Webber MM and Waalkes MP: Chronic arsenic-exposed human prostate epithelial cells exhibit stable arsenic tolerance: mechanistic implications of altered cellular glutathione and glutathione Stransferase. Toxicol Appl Pharmacol 183: 99-107, 2002.

17. Borst P, Evers R, Kool M and Wijnholds J: A family of drug transporters: the multidrug resistance-associated proteins. J Natl Cancer Inst 92: 1295-1302, 2000.

18. Gottesman MM, Fojo T and Bates SE: Multidrug resistance in cancer: role of ATP-dependent transporters. Nat Rev Cancer 2: 48-58, 2002.

19. Szakacs G, Paterson JK, Ludwig JA, Booth-Genthe C and Gottesman MM: Targeting multidrug resistance in cancer. Nat Rev Drug Discov 5: 219-234, 2006.

20. Carmichael J, DeGraff WG, Gazdar AF, Minna JD and Mitchell JB: Evaluation of a tetrazolium-based semiautomated colorimetric assay: assessment of chemosensitivity testing. Cancer Res 47: 936-942, 1987.

21. Mitsuhashi N, Miki T, Senbongi H, et al: MTABC3, a novel mitochondrial ATP-binding cassette protein involved in iron homeostasis. J Biol Chem 275: 17536-17540, 2000.

22. Liu SX, Athar M, Lippai I, Waldren C and Hei TK: Induction of oxyradicals by arsenic: Implication for mechanism of genotoxicity. Proc Natl Acad Sci USA 98: 1643-1648, 2001. 
23. Shudo N, Mizoguchi T, Kiyosue T, et al: Two pyridine analogues with more effective ability to reverse multidrug resistance and with lower calcium channel blocking activity than their dihydropyridine counterparts. Cancer Res 50: 3055-3061, 1990.

24. Sumizawa T, Chen ZS, Chuman Y, et al: Reversal of multidrug resistance-associated protein-mediated drug resistance by the pyridine analog PAK-104P. Mol Pharmacol 51: 399-405, 1997.

25. Nagayama S, Chen ZS, Kitazono M, et al: Increased sensitivity to vincristine of MDR cells by the leukotriene $\mathrm{D}_{4}$ receptor antagonist, ONO-1078. Cancer Lett 130: 175-182, 1998.

26. Bahlis NJ, McCafferty-Grad J, Jordan-McMurry I, et al: Feasibility and correlates of arsenic trioxide combined with ascorbic acid-mediated depletion of intracellular glutathione for the treatment of relapsed/refractory multiple myeloma. Clin Cancer Res 8: 3658-3668, 2002.

27. Dalton WS: Targeting the mitochondria: an exciting new approach to myeloma therapy. Commentary re: Bahlis NJ et al: Feasibility and correlates of arsenic trioxide combined with ascorbic acid-mediated depletion of intracellular glutathione for the treatment of relapsed/refractory multiple myeloma. Clin Cancer Res 8: 3658-3668, 2002.

28. Watson RW, Redmond HP, Wang JH and Bouchier-Hayes D: Mechanisms involved in sodium arsenite-induced apoptosis of human neutrophils. J Leukoc Biol 60: 625-632, 1996.
29. Ding W, Hudson LG and Liu KJ: Inorganic arsenic compounds cause oxidative damage to DNA and protein by inducing ROS and RNS generation in human keratinocytes. Mol Cell Biochem 279: 105-112, 2005.

30. Morales A, Miranda M, Sanchez-Reyes A, Colell A, Biete A and Fernandez-Checa JC: Transcriptional regulation of the heavy subunit chain of -glutamylcysteine synthetase by ionizing radiation. FEBS Lett 427: 15-20, 1998.

31. Leslie EM, Haimeur A and Waalkes MP: Arsenic transport by the human multidrug resistance protein 1 (MRP1/ABCC1). Evidence that a tri-glutathione conjugate is required. J Biol Chem 279: 32700-32708, 2004.

32. Chen ZS, Aoki S, Komatsu M, et al: Reversal of drug resistance mediated by multidrug resistance protein (MRP) 1 by dual effects of agosterol A on MRP1 function. Int J Cancer 93: 107-113, 2001.

33. Lee TC, Ho IC, Lu WJ and Huang JD: Enhanced expression of multidrug resistance-associated protein 2 and reduced expression of aquaglyceroporin 3 in an arsenic-resistant human cell line. J Biol Chem 281: 18401-18407, 2006.

34. Chen ZS, Kawabe T, Ono M, et al: Effect of multidrug resistance-reversing agents on transporting activity of human canalicular multispecific organic anion transporter. Mol Pharmacol 56: 1219-1228, 1999. 